\title{
Penetration of cephaloridine into the subretinal fluid
}

\author{
A. H. GHIGNELL, A. J. BRON, D. L. EASTY, AND D. A. OWEN \\ Moorfields Eye Hospital, City Road, London
}

Cephaloridine is a wide-spectrum antibiotic derived from cephalosporin and, despite similarities to penicillin, it can be used in the treament of infections in penicillin-sensitive patients. Riley, Boyle, and Leopold (1968) and Records (I969) have reported the intraocular penetration of cephaloridine into the aqueous after intramuscular and intravenous administration, and Moll, Crawford, and McPherson (I97I) have shown penetration into the subretinal fluid after subconjunctival injection, but penetration of antibiotic into the subretinal fluid after systemic administration has not hitherto been reported. McMeel (1965), Criswick and Brockhurst (1969), and Lincoff, Nadel, and O'Connor (1970) have described infection after retinal detachment surgery. Langston, Lincoff, and McLean (1965) showed that a purulent endophthalmitis may be produced experimentally with external plombage and diathermy without drainage of subretinal fluid and, although cryotherapy has largely replaced diathermy, the drainage site of subretinal fluid provides a potential route for the entry of organisms into the eye.

In the management of endophthalmitis after retinal detachment surgery, it is not always simple to distinguish between the clinical signs of anterior segment ischaemia (Crock, 1967), a sterile endophthalmitis, and endophthalmitis due to bacterial infection. Before diagnosis can be established, the systemic administration of an antibiotic may be indicated.

In attempting to select antibiotics for the treatment of intraocular infection after detachment surgery, it would be valuable to know what levels of antibiotic are reached in subretinal fluid after systemic administration.

The purpose of this paper is to report the penetration of cephaloridine into subretinal fluid in patients with retinal detachment after intramuscular injection.

\section{Material and methods}

21 patients undergoing routine retinal detachment surgery were studied. In no case were local or systemic antibiotics administered during the week preceding operation. At varying times before surgery ( $1 \frac{1}{1}$ to $2 \frac{1}{2} \mathrm{hrs}$ ), I g. cephaloridine, dissolved in $2.5 \mathrm{ml}$. sterile water, was injected intramuscularly into the gluteal region. In twelve patients $10 \mathrm{ml}$. blood were taken before the injection of cephaloridine. Io ml. venous blood were taken at the time of subretinal fluid collection in all but three cases. Subretinal fluid was obtained by incising the sclera and then partly cauterizing the underlying choroid until the subretinal space was entered. Before puncture of the choroid, the site was carefully dried and haemostasis of the surrounding tissue was secured to avoid contamination of the specimen. A small receptacle (Figure) was held under the puncture wound and subretinal fluid was collected. The fluid was immediately transferred to the laboratory in vacuum flasks 
packed with ice. The blood was allowed to clot and serum was separated by centrifugation and placed in a Bijou bottle. Serum and subretinal fluid were then stored at $-40^{\circ} \mathrm{C}$. Cephaloridine assays of both serum and subretinal fluid were carried out by the agar diffusion method and Bacillus subtilis $84 \mathrm{I}$ in the form of a spore suspension was used as the assay organism. This technique has been described elsewhere by Richards, Bron, Rice, Fells, Marshall, and Jones (1972).

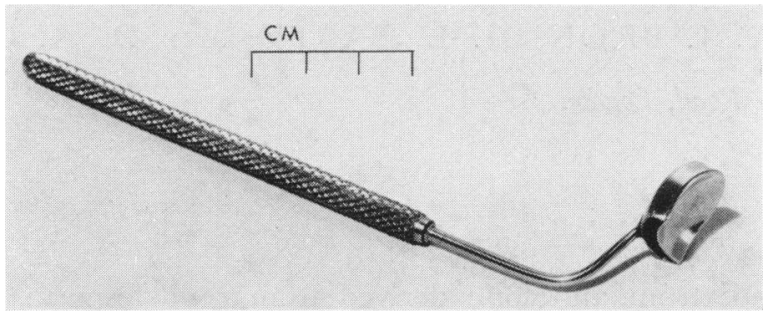

F I G U RE Subretinal fluid collector

\section{Results}

The results are summarized in the Table (opposite). Serum levels of cephaloridine varied from 8.9 to $23.8 \mu \mathrm{g} . / \mathrm{ml}$. at from $\mathrm{I} \frac{1}{4}$ to $2 \frac{1}{2}$ hours after injection. Over the same period, subretinal fluid levels varied from 0.7 to $3.7 \mu \mathrm{g} . / \mathrm{ml}$. No activity was detected in the sera taken before the administration of the antibiotic.

\section{Comment}

The minimum inhibitory concentration of cephaloridine required to inhibit the growth of "sensitive organisms" such as Strep. pyogenes, some Strep. viridans, D. pneumoniae, $\mathcal{N}$. gonorrhoeae, Staph. albus, and penicillin-resistant Staph. aureus varies from 0.005 to I $\mu \mathrm{g} . / \mathrm{ml}$. (after Riley and others, I968), and it is therefore evident that a clinically useful level of cephaloridine may be reached in the subretinal fluid of patients with retinal detachments after a single intramuscular injection of $\mathrm{I} g$. before surgery.

The subretinal fluid antibiotic levels found in the present study are similar to those obtained in primary aqueous by Riley after intramuscular injections of I g. cephaloridine before cataract extraction. This is surprising, since there is known to be a distinct bloodaqueous, which restricts the passage of molecules from the plasma into the aqueous and results in a low concentration of protein in primary aqueous. The relatively high concentration of protein in the subretinal fluid (Chignell, Carruthers, and Rahi, I97 I) results from a limited permeability of choriocapillaris and Bruch's membrane, and this permeability might have been expected to have resulted in higher levels of antibiotic in subretinal fluid than were found. However, in postoperative endophthalmitis, penetration of antibiotic into subretinal fluid and vitreous would be greater, as a result of further increase in vascular permeability resulting from the inflammatory stimulus.

Moll and others (I97I) have shown that significant levels of cephaloridine in the subretinal fluid may be obtained after subconjunctival injection; and they considered that administration by this route was useful as a prophylactic measure. However, it is difficult to assess the values obtained in this study, as the method of collection of subretinal fluid and the precautions taken to prevent contamination from the subconjunctival space are not described. The subconjunctival route of administration is undesirable in inflamed, tender postoperative eyes, particularly when repeated administration is necessary. The 
Table Penetration of cephaloridine into the subretinal fluid after intramuscular injection in $2 \mathrm{I}$ patients

\begin{tabular}{|c|c|c|c|}
\hline $\begin{array}{l}\text { Patient } \\
\text { No. }\end{array}$ & $\begin{array}{l}\text { Time from injection } \\
\text { to collection of } \\
\text { subretinal fluid (hrs) }\end{array}$ & $\begin{array}{l}\text { Serum level } \\
(\mu \mathrm{g} . / \mathrm{ml} .)\end{array}$ & $\begin{array}{l}\text { Subretinal fluid } \\
\text { level }(\mu g . / \mathrm{ml} .)\end{array}$ \\
\hline I & $1 \frac{1}{4}$ & 12.4 & 0.50 \\
\hline 2 & I $\frac{1}{4}$ & 9.4 & 0.80 \\
\hline 3 & 14 & 22.1 & 0.80 \\
\hline 4 & $1 \frac{1}{4}$ & 13.9 & 0.80 \\
\hline 5 & $1 \frac{1}{4}$ & 25.8 & 1.20 \\
\hline 6 & $1 \frac{1}{4}$ & 23.6 & 1.50 \\
\hline 7 & $1 \frac{1}{4}$ & 22.5 & 1.20 \\
\hline 8 & I $\frac{1}{2}$ & I 5.5 & 0.70 \\
\hline 9 & I $\frac{1}{2}$ & 21.2 & 0.70 \\
\hline Io & $I \frac{1}{2}$ & I 5.1 & I.10 \\
\hline I I & $I \frac{1}{2}$ & 12.2 & 1.10 \\
\hline 12 & $1 \frac{1}{2}$ & - & 2.20 \\
\hline 13 & I $\frac{1}{2}$ & - & 2.90 \\
\hline 14 & I $\frac{1}{2}$ & 13.3 & 3.0 \\
\hline 15 & $1 \frac{3}{4}$ & 22.8 & 1.8 \\
\hline I 6 & 2 & - & 1.0 \\
\hline 17 & 2 & 8.9 & 1.50 \\
\hline 18 & 2 & 13.2 & 2.0 \\
\hline 19 & 2 & I 5.9 & 2.40 \\
\hline 20 & 2 & 20.2 & $3 \cdot 70$ \\
\hline 21 & $2 \frac{1}{2}$ & 20.3 & 2.30 \\
\hline
\end{tabular}

injections may be painful and may make further evaluation of extraocular physical signs more difficult. With retrobulbar injections there is an added risk of retrobulbar haemorrhage.

\section{Conclusion}

Therapeutic concentrations of antibiotic were found in the subretinal fluid of patients undergoing routine retinal detachment surgery after a single intramuscular injection of I g. cephaloridine. It is therefore suggested that the drug given by this route will be useful in the treatment of known or suspected intraocular infections after retinal detachment surgery. It also seems likely that, in cases of bacterial endophthalmitis not necessarily associated with retinal detachment, the passage of antibiotic from the choriocapillaris across Bruch's membrane and the pigment epithelium would produce a useful level of antibiotic in the eye.

This work was in part supported by the Clothworkers' Company. The cephaloridine assays were performed by M. Marshall of the Glaxo Company, Ltd. 


\section{References}

Chignell, A. H., CARruthers, M., and RAHI, A. H. s. (1971) Brit. F. Ophthal., 55, 525 CRISWICK, v. G., and BROCKHURST, R. J. (1969) Arch. Ophthal. (Chicago), 82, 64I CROCK, G. (1967) Trans. ophthal. Soc. U.K., 87, 513 LANGSTON, R., Lincoff, H. A., and McLeAN, J. M. (1965) Arch. Ophthal. (Chicago), 74, 665 LINCOFF, H. A., NADEL, A., and o'Co NNOR, P. (1970) Ibid., 84, 421 MCMEEL, J. W. (1965) Ibid., 74, 45 MOLL, T. B., GRAWFORD, J. R., and McPHERSON, s. D. (1971) Amer. J. Ophthal., 71, 992 RECORDS, R. E. (I969) Arch. Ophthal. (Chicago), 81, 33 I Richards, A. B., Bron, A. J., RICE, N. s. C., FELls, P., MARshall, M., and JONES, B. R. (1972) Brit. 7. Ophthal., 56, $53^{\mathrm{I}}$

RILEy, F. C., BOYLE, C. L., and LeOPold, I. H. (I968) Amer. J. Ophthal., 66, I042 